\title{
What if none of the building stones at Stonehenge came from Wiltshire?
}

Article

Accepted Version

Whitaker, K. A. (2019) What if none of the building stones at Stonehenge came from Wiltshire? Oxford Journal of Archaeology, 38 (2). pp. 148-163. ISSN 1468-0092 doi: https://doi.org/10.1111/ojoa.12161 Available at https://centaur.reading.ac.uk/80442/

It is advisable to refer to the publisher's version if you intend to cite from the work. See Guidance on citing.

To link to this article DOI: http://dx.doi.org/10.1111/ojoa.12161

Publisher: Wiley

All outputs in CentAUR are protected by Intellectual Property Rights law, including copyright law. Copyright and IPR is retained by the creators or other copyright holders. Terms and conditions for use of this material are defined in the End User Agreement.

\section{www.reading.ac.uk/centaur}

\section{CentAUR}

Central Archive at the University of Reading

Reading's research outputs online 
WHAT IF NONE OF THE BUILDING STONES AT STONEHENGE CAME FROM WILTSHIRE?

\section{Building stones at Stonehenge}

\section{KATY A. WHITAKER \\ University of Reading}

\section{ACKNOWLEDGMENTS}

In 2016, the conveners of the third Neolithic and Early Bronze Age Research Students' Symposium threw down a gauntlet. The provocation, 'Anarchy in the UK?', challenged speakers to construct alternative pasts diverging from, disrupting, or inverting, linear narratives of social evolution in the period c. $4000 \mathrm{cal}$. BC - c. 1500 cal. BC. This paper resulted from that challenge. This work was supported by the Arts and Humanities Research Council (grant number AHIL503939\1) through the South, West, and Wales Doctoral Training Partnership.

\section{ABSTRACT}

The sarsen and bluestone stones at Stonehenge (Wiltshire, UK) have played a significant role in the development of twentieth-century ideas about Neolithic and early Bronze Age social structure. Sarsen and bluestone are not, however, the only rock types used at Stonehenge. The varied stones present at the monument include previously under-studied material, such as the normally unseen, and largely forgotten, packing stones for Stonehenge's famous settings. By reflecting on more recently developed theoretical frameworks to interpret this variety, this paper exposes the possibility that an alternative to the dominant discourse, in which Stonehenge represents the culmination of Neolithic social evolution, is possible.

\section{INTRODUCTION}

So, what if none of the building stone at Stonehenge came from Wiltshire? This thought experiment starts with the revolutionary proposition that not only the exotic Welsh bluestones, but all of Stonehenge's building stones are 'foreign' to the region. 
The purpose is to discuss the role of Stonehenge's stones in some 60 years of debate about Neolithic and early Bronze Age social structure. Stonehenge has played - still plays - a key role in ideas about how prehistoric communities were organised, involved, engaged with one another, and with the environment, landscape, and resources around them. How immense stones were sourced and moved to the monument, from one location in south-west Wales and another in north Wiltshire, is central to these ideas. The vision of this herculean effort colours understanding of the complexity of Neolithic and early Bronze Age society: from Richard Atkinson's "shadowy and insubstantial" $(1956,165)$ ruler of men directing thousands of labourers, to Colin Renfrew's (1973) hypothetical Wessex chieftain in command of local tribal groups.

More recent archaeological theory presents more nuanced and dynamic readings of monument building than previous culture-historical or processual interpretations. Instead of hierarchal political power enabling large-scale prehistoric construction projects, archaeologists, such as Barrett (1994) and Richards (2013) among others, have drawn on agency theory and ethnographic analogy to propose that multiskilled, multi-faceted, long-term, building episodes were performative acts in which social relationships and personal positions were negotiated, built up, and, perhaps, broken down. If Stonehenge's stones came from more dispersed sources, they could have been brought to Salisbury Plain by far more varied, heterogeneous, groups of participants whose choices, decisions, and actions sometimes chimed, sometimes contradicted, but ultimately, contributed to social change.

Having wondered where Stonehenge's building stones came from, this paper looks in more detail at what those building stones actually were and where their sources might have been located. It considers the unsung (because largely unseen) packing stones that were essential supports, both physically and metaphysically, to the massive upright settings familiar to visitors today, and touches on the Welsh bluestones - which quite clearly did not come from Wiltshire. Finally, it addresses sarsen stones, the biggest of Stonehenge's megaliths that form the iconic lintelled shapes recognised around the world. These are rocks best known in Wiltshire but which, in Britain, can be sourced as far afield as Kent in south-east England. 
If it is possible that none of Stonehenge's building stones came from Wiltshire, what are the implications for understanding prehistoric social structure? The paper suggests that an alternative to the dominant twentieth-century discourse in which Stonehenge represents the culmination of Neolithic social evolution, is possible.

\section{STONEHENGE IN SOCIETY}

During the later twentieth-century, interpretations of Neolithic barrow, enclosure, henge, mound, and stone circle building developed in which increasingly labourintensive construction through time, and therefore of inferred complexity of resourcemanagement requiring control and leadership, was seen to indicate concomitant centralisation of political authority. The outstanding example in the archaeological literature, described by Josh Pollard in 2013 as 'sticky' because of the way it has hung around in the debate since its publication more than 40 years ago, is Colin Renfrew's 1973 paper "Monuments, mobilisation and social organisation in Neolithic Wessex." Taking his lead from Atkinson's (1961) estimations of workloads to build Stonehenge's stone settings, and demanding that prehistoric monumentality needs to be accounted for, Renfrew applied concepts of tribe and chiefdom described by anthropologists to the archaeological record. He hypothesised that "developed social stratification" $(1973,542)$, culminating in the over-lordship of five theoretical Wessex tribes by a great chieftain $(1973,552)$, explained the construction of Silbury Hill and the complex stone settings at Stonehenge (Wiltshire). In this endogenous explanation of culture change, these monuments "are seen as the natural counterpart of other features of the society." (Renfrew 1973, 556)

More recently archaeologists have been exploring the contrasting idea that Neolithic monument construction provided conditions in which social differentiation could develop. Barrett (1994) for example, disputed the notion that massive stone settings like those at Avebury or the timber settings within Durrington Walls (both in Wiltshire) represent monuments imagined by such a great chieftain. Instead, he proposed that it was in the making, in using, and in further altering and re-using these architectural sets or stages, that social relationships, authority and power were generated (Barrett 1994, 13, 23, 29-32). Richards $(2004,74)$ developed this concept when he observed that building a megalithic monument "is more than a means to an end." Rather than 
such a monument being an index of existing political power, the initial desire to build provided the environment in which social relationships were materialised and negotiated in order to prepare for and then carry out the work. And Cooney (2008, 208-9), for example, has brought this idea into the realm of everyday Neolithic encounters with stone, suggesting that social relationships were inflected and informed even at smaller scales - knapping, post-packing, clearance cairn-building, for example - as people worked together day-to-day.

The henge earthworks, stone settings, and avenue at Stonehenge play a prominent role in such contrasting interpretations. In 1973 Stonehenge's sarsen stone settings were placed in Atkinson's (1956) Phase Illa-c of the monument's re-development: whilst the smaller and, on the whole, less impressive, bluestones belonged to his Phase II. Renfrew $(1973,548)$ proposed that the estimated 30 million hours of labour for Phase III construction represented the peak of a hierarchy of labour that had its origins, on the smallest scale, with earlier Neolithic long barrow building. It is hardly surprising that Stonehenge's unique sarsen settings of five immense trilithons and a ring of lintelled uprights should, in this model, be representative of control of an equally immense labour force by a powerful leader over the years of construction (Fig.1). For Barrett (1994, 29), however, the "inner façade-like setting of the trilithons" at Stonehenge was the stage on which people were able to take up leading roles: construction had created a new space in which only specific actors would come to shine.

\section{STONEHENGE IN WILTSHIRE}

To return to this paper's question: in one, rather obvious, sense none of Stonehenge's stones came from Wiltshire. This is a prehistoric monument in an Anglo-Saxon county: the administrative boundary of the people of Wilton is irrelevant. But modern areas and names are useful to think with. Stonehenge has enjoyed a very long life. Comprised of earthworks, lost timber features, surviving stone settings erected and altered at different times, it includes rocks from as far afield as south-west Wales. Some of its building stones, however, have long been assumed to have come from what we now call Wiltshire. 
Surviving at the monument today are 37 upright sarsen stones (including supported lintels), 15 fallen sarsen stones, 14 standing bluestones, 15 fallen bluestones, and 10 bluestone stumps (Cleal et al. 1995) (Table 1). The monument's other building stones are the hundreds of packing stones and rocky packing material placed into stoneholes to support the uprights. This material has been singularly ignored in discussions about the monument's overall construction. One such packing stone type is Chilmark stone. This Jurassic limestone, formed between 146 and 151 million years ago, was found by William Hawley (1922) to have been used as a packing material in the stoneholes for Stone 1, Stone 29, and Stone 30.

Chilmark stone is a component of the Portland beds of the Vale of Wardour anticline, found some $19 \mathrm{~km}$ to the south-west of Stonehenge (Fig. 2). Its geographical limits are to a small area either side of the Nadder Valley: to the north, between Fonthill Bishop and Chilmark villages; to the south, between Wockley and Chicksgrove. At this location, the Portland beds are c. $33 \mathrm{~m}$ thick, of which the top c. $6 \mathrm{~m}$ in the sequence are pale grey, fine-grained, limestones (Geddes 2003, 45). Chilmark stone has been quarried for many years, extracted from open and underground quarries in the side of the Chilmark Ravine where the member is c. $4 \mathrm{~m}$ thick (Hopson et al. 2007, 10). Whilst Romano-British material excavated in the environs hints at the possibility of earlier stone exploitation, the quarries around Chilmark village were Wiltshire's most significant stone source of the Middle Ages, used especially for churches including both Salisbury and, further afield, Rochester cathedrals. The neighbouring Chilmark stone quarries around the village of Teffont Evias were similarly productive (Crittall 1959, 247-9).

Stonehenge's sarsen circle, of which Stones 29, 30, and 1 are in the north-east arc, was erected 2,580 - 2,475 cal. BC (Darvill et al. 2012, 1033). Chilmark stone was deployed in at least these three of the circle's stoneholes (and it should be borne in mind that not all of the circle's stoneholes have been excavated), in which it comprised a significant proportion of the packing stones. The presence of stone from such a restricted source begs the question: why this stone? And as well as Chilmark stone, Hawley identified other stone types in the packing material that are not from the Stonehenge basin's chalk geology: glauconite and oolite, along with Hurdcott stone $(1922,44)$ (Table 2). 
It is not clear what Hawley meant by glauconite. It could have been a Greensand: Wiltshire is the type locality for Upper Greensand, a Cretaceous sand rich in the ironpotassium silicate mineral called glauconite (Geddes 2003, 49). As the crow flies, the nearest Upper Greensand to Stonehenge is the formation in the Vale of Pewsey c. $15 \mathrm{~km}$ to the north, where a few rock layers are hard enough for building purposes (Booth et al. 2010, 23; Geddes 2003, 76). The Shaftesbury Sandstone scarps and ridges of the formation in the Vale of Wardour are to the south-west (Hopson et al. 2007, 13). Here, c. $14 \mathrm{~km}$ from Stonehenge, Hurdcott Greenstone is still being quarried for architectural purposes by the Lovell Stone Group at the Barford St Martin quarry (Fig. 2). Hurdcott stone can be seen in buildings in Mere, is identifiable in various Norman churches in south Wiltshire, and is often seen in foundations or as part of a damp course for brick and timber buildings in this locality (Geddes 2003, 79-80).

Despite the relative proximity to Stonehenge of sources for these rocks, it is nevertheless quite possible, in geological terms, that some came from locations much further away. Upper Greensand building products, for example, have been taken from quarries in the environs of Shaftesbury (Geddes 2003, 195) some $32 \mathrm{~km}$ west of Stonehenge. Exposures of the sequence can be seen further afield such as in cliffs to the west of Upper Branscombe (Devon) (Hamblin 2013, 134 fig. 2): whilst the Reigate Stone quarries in Upper Greensand in east Surrey provided one of the most commonly-used freestones for medieval building in London, the earliest documentation of surface quarrying there dating to the early-thirteenth-century (Tatton-Brown 2001).

The few packing stones from sarsen Stonehole 8 identified as oolite by Hawley $(1926,6)$ might have come from the top of the sequence at Chilmark, the only oolitic source in the Tisbury/Chilmark Stone Portlandian sequence in the Vale of Wardour (Hopson et al. 2007, 33). Alternatively, they could have been sourced from one of the next nearest sources, the Great and Inferior Oolite Groups in the environs of Box Hill, c. $40 \mathrm{~km}$ to the north-west, and c. $36 \mathrm{~km}$ to the west near Frome (Fig. 2). But Hawley's generic identification does not prohibit them from being brought to 
Stonehenge from as far afield as the extensive oolite outcrops in Northamptonshire, Lincolnshire, or Yorkshire.

Did this range of Stonehenge packing material really comprise local stones? It is remarkable that Hawley (1922) supposed that glauconite and Chilmark stone were used during the erection of Stone 30 because there was too little local sarsen for packing material, "consequently stone had to be searched for and brought from distant places" $(1922,42)$. This despite the fact that he had found 363 quartzite sarsen cobbles in the environs of Stones 1 and $30(1922,37)$ having stripped the turf and topsoil to expose the archaeological layers. The oolitic stone, whether from Bath or Barnack, as those other packing stones, were brought to the monument in prehistory regardless of the availability of local sarsen: and were brought by people, not a geological process such as a result of glaciation, a point noted by Green (1997, 260). Not only that: although close to the surface, rocks in the Wiltshire locations mentioned are unlikely to have been exposed, and to be found had to have been dug for. I would suggest that these stones are akin to the cairn material at dolmens discussed by Richards (2004), present at monuments not merely as waste but just as important as the large stones selected for the architectural form we recognise as a monument $(2004,78)$.

What does 'local' mean? Does it, in the context of ideas about resource management and organisation in prehistory, mean 'convenient'? How far does something have to travel before the distance becomes significant to us? If 'local' means a walk there and back in a day, then it changes with the seasons as the days lengthen and shorten - assuming that travelling is conducted in daylight. Or 'local' could mean to the horizon and back. In these senses, certain of Stonehenge's building stones were neither from Wiltshire nor local: the bluestones from locations in south-west Wales.

\section{SPECIAL STONES}

Igneous rocks at Stonehenge, present as standing and fallen stones, buried stumps, implements, and stone chips throughout deposits across the site, were first identified petrologically in the 1920s (Thomas 1923). The Preseli mountains in Pembrokeshire 
are c. $230 \mathrm{~km}$ as the crow flies from Stonehenge and the monument's variety of stone types from outcrops in that region are still subject to investigation (including recently Ixer and Bevins 2016). Parker Pearson et al. (2016) have identified prehistoric bluestone quarrying at Craig Rhos-y-felin, following the provenancing of chips known as 'rhyolite with fabric', found in the Stonehenge area, to that isolated outcrop by Ixer and Bevins (2011).

Possible glacial explanations for the presence of bluestone in Wiltshire have been firmly contradicted on a number of grounds (Darrah 1993; Green 1973, 1997; Pitts 2000; Bevins et al. 2016). Whilst various reasons have been theorised to explain the prehistoric human transportation of bluestones over such a challenging distance to the Salisbury Plain, the common theme in all is the special nature of the stones, whatever they signified. Interestingly, Atkinson $(1956,175)$ centred this significance in the materiality of the very mountains themselves. Parker Pearson et al. (2015, 1350) ascribe ancestral identities to the specific stones selected for transportation, for example. More generally, Jones (2007) comments on the importance of the connections that were made between one place, a stone source, and another, its monumental place of use: for Jones, "[s]tone is a material that embodies the significance of place" $(2007,184)$. Thus, the prehistoric selection and use of specific stony material was an act of engaging with particular qualities, special places, sacred associations; and transporting these qualities to new locations, re-worked into new forms.

The idea that already special stone could be re-worked into new, different, special structures is not unfamiliar to accounts of Stonehenge. Two of the uprights (67 and 70) in the bluestone horseshoe appear to have had tenons; Stones 150 and 36 appear to have been lintels once, because they have mortice holes; Stone 69 has a dished top; whilst Stone 66 and Stone 68 appear once to have been attached to one another (or to other similarly shaped, but now lost, stones) by means of a carved tongue and groove arrangement (Cleal et al. 1995, 29). These stones are long thought to have originated in an earlier setting which, although it could have been at Stonehenge, is just as likely to have stood elsewhere prior to re-use at the monument. Thomas $(1923,258)$ suggested that a stone circle in the Preseli mountains had been translated to Salisbury Plain: most recently, Parker Pearson et 
al. $(2016,23)$ have mused that a Pembrokeshire passage tomb was dismantled and re-used at Stonehenge.

The possible special nature of otherwise apparently 'local' stone, or raw stone in its natural state prior to extraction, has been touched on by David Field (2010). Referring to traditional, un-mechanised, quarrying practices that are bound up in rituals, carried out by people intimately familiar with places, Field raises the possibility that stony places in the landscape had long-standing cultural associations (2010, 169-70). Far from being a neutral or inanimate resource available for economic exploitation in which the best material, in technological terms, will be targeted, stone has a multiplicity of characteristics. These include agential qualities, as highlighted by Gillings and Pollard (1999) who imagine people encountering sarsens, visible as they are around Avebury on the ground surface, in the early third millennium BC prior to stones' eventual use in Avebury henge's great stone settings. These strange rocks are unlike so many of the others that can be found; they include immense boulders, unlike the flint cobbles and pebbles that can be found in the soil or streambeds; they lie about in the vegetation, not raised up in the craggy cairns and tors of the igneous West, for example; their scattered presence in some locations, but not others that are apparently similar in all other respects, requiring an explanation.

It is likely that sarsens had become special stones through such accrual of meaning and enmeshing in myth and story (Field 2005, 89-90; Gillings and Pollard 1999, 183). The authors take this further when considering examples of smaller, often non-structural, sarsens in Neolithic long mounds (Pollard and Gillings 2009), identifying these to have been significant stones playing key roles in the initiation of each mound-building process. Smaller boulders with no clear structural importance, such as the sarsens placed in the Beckhampton Road long mound, may have been vested with cultural importance for some time prior to their appropriation for the monument $(2009,36)$. In contrast to these insights from the Avebury landscape, and while considerable attention has been paid to Stonehenge's 'special' bluestones, the focus on its sarsens has commonly been restricted to technological questions to do with working and moving these vast, dense, indurate blocks. 


\section{WILTSHIRE IN STONEHENGE}

Like Chilmark and Hurdcott stone and their possibly near neighbours the glauconite and oolite, sarsen stone is found in Wiltshire. Whilst the archaeological literature includes some proposals about how close to the Stonehenge basin sarsens could have been found in prehistory (McOmish et al. 2002, 152; Bowden et al. 2015, 40-2), the prevailing view is that the monument's sarsens were sourced in the Kennet Valley and on the Marlborough Downs some $30 \mathrm{~km}$ to the north (Fig.2).

There are a number of strong and persistent reasons for this assumption. Partly, it is to do with its antiquity. The oldest published suggestion that the Marlborough Downs were the source for Stonehenge's sarsens dates to the early sixteenth-century (Lambarde, $1730 \mathrm{Edn}$ ). Authorities including Inigo Jones in the seventeenth-century and John Aubrey, who had known Salisbury Plain since his youth, agreed (Britton 1847, 44; Fowles 1980, 36), as did William Stukeley $(1740,5)$. Although these carried less weight with Judd (1902), Stone (1924), Thomas (1923), and Thorpe et al. (1991) it remains the prevailing view reinforced by, amongst many others, such authorities as Atkinson (1956), Cleal et al. (1995), Scourse (1997), Tilley et al. (2007). Fieldwork in 2011 and 2012 carried out in Clatford Bottom (Wiltshire) by the Stones of Stonehenge Project was based on the assumption, and driven by William Stukeley's drawing of large sarsens in the area (Parker Pearson 2012, 292-302).

The assumption is also coloured by the way in which the bluestones have long been characterised as 'other', casting the sarsen, so clearly available in Wiltshire, in the role of a 'local' stone. Both Gowland (1902) and Hawley, throughout his excavation reports of the 1920s, consistently referred to bluestone as the "foreign" stone. In this sense, bluestone is special, sarsen is not. In north Wiltshire sarsen is obvious, and has been for many years: famously, Richards Simmonds could write a diary entry in 1644 claiming that in one parish it was possible to walk for a mile and a half stepping from one sarsen boulder to another (ed. Long 1859) (Fig.3). In those places where sarsens are visible on the surface, they are inevitably presumed to have been the source for the nearest prehistoric stone settings in sarsen. This is just as true in Dorset as Wiltshire, for example. In recommending a visit to the Valley of Stones near to Portesham, Grinsell and Dyer $(1971,20)$ remark "[t]his valley is of interest in 
that it probably provided the stones for the various megalithic monuments in the vicinity" for which the visitor will undoubtedly be making the trip.

A further aspect of this visibility is the so-called 'sarsen villages' of the Marlborough Downs. Atkinson $(1956,111)$ claimed, "it is only around Avebury that sarsen is used for building at all." This led him to conclude that further south on Salisbury Plain, where there are apparently no similar villages, there had been no such natural concentrations of sarsen stone. Buildings in Kennet Valley villages near Avebury, constructed in sarsen, are a very important element of the local sense of place and architectural character (Fig. 4) and the 'sarsen village' argument is often repeated despite the fact that sarsen use in construction is in fact more commonplace across its geological range than these assertions claim. Examples increasingly distant from Avebury include buildings in Chiseldon (Wiltshire), Aldbourne (Wiltshire), Lambourn (Berkshire), and Letcombe Regis (Oxfordshire).

\section{SARSEN BEYOND WILTSHIRE}

Taking the exotic bluestones as the exemplar of long-distance transportation, Mike Parker Pearson $(2016,368)$ has recently reflected on the possibility that the selection of Stonehenge's sarsens had less to do with local convenience than the assumptions described above prescribe. If special stone, and special stones, were selected for use in Stonehenge, what is to stop the monument's sarsens having come from a wider source area than the Marlborough Downs? Is it actually possible for sarsen stones to have been brought to Salisbury Plain from locations outside of Wiltshire?

The in situ locations, in a geological sense, of sarsen stone in southern England are unknown. The UK's sarsen boulders and cobbles are predominantly groundwater silcretes. These rocks formed when silica accumulated in near-surface Tertiary sediments, commonly over-lying older Cretaceous geology such as the chalk of central and southern Wiltshire, cementing the younger sands, gravels and pebbles to form an indurated duricrust. The host deposits have been subject to later geological erosion processes, removing much, if not all, of any un-silicified sediments to leave cemented boulders and cobbles free. Subsequent periglacial action, and the 
boulders' long exploitation by people, result in the discontinuous present-day distribution (Ullyott and Nash 2016, 311-2; Huggett 2016, 298). The 'natural' distribution of sarsen stone in the UK is on the whole an archaeological concept, referring to the geographic availability of the dispersed sarsen fields to people from the Mesolithic onwards. The current best depiction of this dispersed distribution is that mapped by Ullyott et al. (2004, 1511 fig. 1): whilst clearly showing the intensity of sarsen survival in Wiltshire, the wider availability of the stone from Dorset to Kent is made clear.

Certain characteristics of the selected stones, however, appear to have been important to the people making Stonehenge. Where ever they came from, certain boulders had to have been big enough. This is a very difficult aspect of sarsen sourcing to investigate today, precisely because of the more recent exploitation of sarsen especially in the modern era. There are very few large sarsens remaining in the field. Two surviving examples include the Toad Stone (Fig. 5) and an immense boulder on Monkton Down, both in north Wiltshire. The Upper White Horse Stone, Aylesford (Kent) is another large survival, and there are still three very large sarsens on Odstone Down to the east of Weathercock Hill, marking the administrative area boundary (Lambourn Downs, Oxfordshire). But on the South Downs in Sussex, for example, although some large sarsens are present, the average length available today is c. 2 m (Ullyott et al. 2004, 1522): a survey of the sarsens on Fyfield Down, Wiltshire, would likely return similar results.

A more accessible aspect of Stonehenge's sarsens is their visual appearance. The possible importance of the colour of selected sarsens has been commented on, for example by Atkinson (1956, 2-3), and by Tilley et al. $(2007,196)$ noting the positioning of greyer and browner stones in Stonehenge's trilithon arrangement. Similar comments have been made about sarsens in other monuments: Pollard and Gillings $(1998,157)$ remarked on the tinge of red seen in certain stones selected for settings at Avebury henge, for example. Variability in the external colours of sarsen stones can be seen across the geographic range (Fig. 6), sometimes influenced not only by levels of iron oxide in the stone itself but also by biological factors. And whilst nineteenth-century quarrymen in Buckinghamshire, for example, located sarsens buried in clay-with-flints by probing (Green 2016, 357 fig. 9), in many areas 
the boulders are readily visible where they lie on the surface. Although there is not the space here to explore the nature of prehistoric sarsen extraction practices, the point is that across its natural distribution the stone is commonly visible, and not only in Wiltshire.

That these boulders outside of Wiltshire were seen and used in the Neolithic is clear. A fine example is Kit's Coty House long barrow in Kent, where four large sarsens of the originally-covered burial chamber are now exposed. Other sarsens are likely to have been in position as a revetment to the (now destroyed) earthen mound of the barrow. It sounds trite to make this point in the face of the monumental evidence, but during the Neolithic people were not unaware of these stones, whether Medway or Marlborough sarsens, and made decisions to interact with them in a variety of ways. Whilst it is now very difficult to demonstrate the likely availability of large sarsens in possible source locations across its natural distribution, other characteristics such as colour variation in boulders, and the visibility and availability of sarsen beyond Wiltshire's boundaries, are more easily demonstrated.

\section{COALS TO MANCHESTER, OR, SARSENS TO WILTSHIRE}

Bringing stones to Stonehenge, shaping and dressing some of them, erecting them, re-configuring the settings, are all activities that occurred over a long period of time in the third millennium cal. BC (Darvill et al. 2012, 1026 table 3). The heights of these laborious exercises, perceived as the culminations of pre-imagined and planned building episodes (albeit to a timeframe not yet informed by radiocarbon dating), heavily influenced Richard Atkinson 60 years ago when he described "a single man" in control of Neolithic communities, "who alone could create and maintain the conditions necessary for this great undertaking" (Atkinson 1956, 165). Renfrew's (1973) conceptualisation of Neolithic social organisation, informed by the anthropological literature and describing the evolution of tribal and chiefdom systems in Wessex, is similarly underpinned by the perceived enormity of the undertaking to move more than 75 sarsen stones some $30 \mathrm{~km}$ into the Stonehenge basin.

Ideas about where Stonehenge's 75+ sarsens came from have a strong influence on the visualisation of prehistoric social organisation. If the stones came from the 
Marlborough Downs, they require the route. Richard Atkinson drew one dotted line (1956, 112 fig. 4), Mike Parker Pearson (2016, 364 fig. 2) another, but what these have in common is that one line on a map looks like a mass-movement. The huge physical effort along the route, its vision of immense numbers of people moving some number of large boulders in one direction before walking back for more, has a 'corporate-ness' about it. Furthermore, the route has a tendency to diminish the lengthy duration of the construction process, this reduction being a problem highlighted by Richards $(2004,74)$. Consequently, an outcome of the route is that it supports the concept of monument building as a unitary process.

In contrast, Richards $(2004,2013)$ has encouraged us to think differently about monument construction, rejecting the concept of building solely intended to result in a final structural form, the fulfilment of one person's architectural vision. Instead, "the main social focus is the process of construction" (Richards 2004, 73). An important aspect of this alternative way of looking at megalithic monuments is the recognition, via ethnographic evidence, that individual stones are likely to have held significance "as material entities" (Richards 2013, 26) in their own right, not only because of certain innate physical qualities but also because of their origin story, special source, or attributed qualities arising from ongoing human interaction with them.

Similarly, Pollard and Gillings (2009) have highlighted the importance of individuallysignificant sarsens stones in, for example, earlier Neolithic long barrow construction (2009, 35-7) as well as in the later great stone circle settings of a monument like Avebury. Perhaps individual stones in a megalithic setting like Stonehenge (and the stones arranged in any dolmen, circle, or alignment) could each be recognised as the work of but one of many social groups (Richards 2004, 77) rather than being the expression of power of Renfrew's "Salisbury Plain chief” $(1973,553)$. Stonehenge's other building stones, the packing material, cast another light on the significance of stone selection. The presence of non-local limestone drystone walling in long barrows such as the West Kennet megalithic chambered tomb (Piggott 1962, 14, 58) has attracted comment: in such monuments, we see early examples of practices of stone collection, transportation, and mixed use that are also evidenced by 
Stonehenge's Chilmark, Hurdcott, glauconite and oolite stones that William Hawley observed but which have since been largely ignored.

Just as the stonehole packing stones at Stonehenge were not simply discarded rubbish used expediently, but carefully selected materials gathered from some kilometres away, so the individual sarsens each were significant stones wrapped up in, as Richard's puts it, "the extended web of social practices surrounding the building of a monument" $(2013,7)$. Not only the Welsh bluestones, but all the stony building materials at Stonehenge were brought from varying locations, travelling over variable distances. The majority of these locations are yet to be ascertained with certainty, for whilst the lithology and petrography of the bluestones are readily susceptible to analysis enabling their sources to be identified, similar work has yet to be carried out on those other rock types. Nevertheless, it remains a possibility that Stonehenge's sarsens came from further afield than the Marlborough Downs, and that instead of a map showing the route of these boulders, a set of snaking paths across southern England could be revealed. Whilst I do not want to deny the major undertaking that was moving just one megalith in prehistory, a more nuanced view of the stony variety at Stonehenge is possible. If none of Stonehenge's building stones came from Wiltshire, but were contributed over time in a series of collaborative undertakings by varied groups of people from far and wide, then the monument might typify social differentiation as the outcome of, rather than the precursor to, prehistoric monument building. 


\section{REFERENCES}

ATKINSON, R.J.C. 1956: Stonehenge (London).

ATKINSON, R.J.C. 1961: Neolithic engineering. Antiquity 35, 292-9.

BARRETT, J.C. 1994: Fragments from Antiquity. An Archaeology of Social Life in Britain, 2900-1200BC (Oxford).

BEVINS, R., ATKINSON, N., IXER, R., EVANS, J. 2016: U-Pb zircon age constraints for the Ordovician Fishguard Volcanic Group and further evidence for the provenance of the Stonehenge bluestones. Journal of the Geological Society 174(1), 14-17.

BOOTH, K.A., HOPSON, P.M., FARRANT, A.R., NEWELL, A.J., MARKS, R.J., BATESON, L.B., WOODS, M.A., WILKINSON, I.P., EVANS, D.J. 2010: Geology of the Devizes District - a brief explanation of the geological map. Sheet Explanation of the British Geological Survey. 1:50 000 Sheet 282 Devizes (England and Wales). (Keyworth).

BOWDEN, M., SOUTAR, S., FIELD, D., and BARBER, M. 2015: The Stonehenge Landscape. Analysing the Stonehenge World Heritage Site (Swindon).

BRITTON, J. (ed.) 1847, 1969 Edn: The Natural History of Wiltshire by John Aubrey F.R.S. written between 1659 and 1691 (Newton Abbot).

CHIPPENDALE, C. 1994: Stonehenge Complete (London).

CLEAL, R., WALKER, K. and MONTGAGUE, R. 1995: Stonehenge in its Landscape (London).

COONEY, G. 2008: Engaging with stone: making the Neolithic in Ireland and Western Britain. In FOKKENS, H., COLES, B.J., VAN GIJN, A.L., KLEINE, J.P. 
PONJEE, H.H. and SLAPPENDEL, C.G. (eds.), Between Foraging and Farming (Leiden, Analecta Praehistorica Leidensia 40), 201-14.

CRITTALL, E. (ed.) 1959: A History of Wiltshire. Volume 4 (London).

DARRAH, J. 1993: The Bluestones of Stonehenge. Current Archaeology 134, 78.

DARVILL, T., MARSHALL, P., PARKER PEARSON, M. and WAINWRIGHT, G. 2012: Stonehenge Remodelled. Antiquity 86(334), 1021-40.

FIELD, D. 2005: Some observations on perception, consolidation and change in a land of stones. In BROWN, G., FIELD, D. and MCOMISH, D. (eds.), The Avebury Landscape. Aspects of the field archaeology of the Marlborough Downs (Oxford).

FIELD, D. 2010: Pen Pits, New Grange and progress in the archaeology of extraction. In BREWER-LA PORTA, M., BURKE, A. and FIELD, D. (eds.), Ancient Mines and Quarries - a trans-Atlantic Perspective (Oxford).

FOWLES, J. (ed.) 1980: Monumenta Britannica or A Miscellany of British Antiquities by Mr John Aubrey...compiled mainly between the years 1665 and 1693 (Sherbourne).

GEDDES, I. 2003: Hidden Depths: Wiltshire's Geology and Landscapes (Bradfordon-Avon).

GILLINGS, M. and POLLARD, J. 2010: Non-portable stone artefacts and contexts of meaning: the tale of Grey Wether (www.museums.cls.ac.uk/Avebury.stone4.htm) In MARSHALL, Y. and GOSDEN, C. (eds.), The Cultural Biography of Objects. World Archaeology 31(2), 179-193.

GOWLAND, W. 1902: Recent excavations at Stonehenge. Archaeologia 58(1), 37118. 
GRINSELL, L. and DYER, J. 1971: Discovering Regional Archaeology. Wessex (Tring).

GREEN, C.P. 1973 Pleistocene River Gravels and the Stonehenge Problem. Nature 243, 214-6.

GREEN, C.P. 1997 The provenance of rocks used in the construction of Stonehenge. In CUNLIFFE, B. and RENFREW, C. (eds.), Science and Stonehenge (Oxford, Proceedings of the British Academy 92), 257-70.

GREEN, C.P. 2016: The exploitation of silcretes (sarsen and puddingstones) in England and Normandy since Stonehenge. Proceedings of the Geologists' Association 127, 349-58.

HAMBLIN, R. 2013: The Upper Greensand of the Haldon Hills and East Devon. Mercian Geologist 18(2), 133-8.

HAWLEY, W. 1922: Second report on the excavations at Stonehenge. Antiquaries Journal 2, 36-52.

HAWLEY, W. 1926: Report on the excavations at Stonehenge during the season of 1924. Antiquaries Journal 6, 1-25.

HOLMES, S. C. A. 1981: Geology of the country around Faversham (London).

HOPSON, P.M., FARRANT, A.R., NEWELL, A.J., MARKS, A.J., BOOTH, K.A., BATESON, L.B., WOODS, M.A., WILKINSON, I.P., BRAYSON, J. and EVANS, D.J. 2007: Geology of the Salisbury District - a brief explanation of the geological map. Sheet Explanation of the British Geological Survey. 1:50 000 Sheet 298 Salisbury (England and Wales) (Keyworth).

HUGGETT, J. 2016: Puddingstones and related silcretes of the Anglo-Paris Basin an overview. Proceedings of the Geologists' Association 127, 297-300. 
IXER, R.A., and BEVINS, R.E. 2011: Craig Rhos-y-felin, Pont Saeson is the dominant source of the Stonehenge rhyolitic 'debitage'. Archaeology in Wales 50, 21-32.

IXER, R.A. and BEVINS, R.E. 2016: Volcanic Group A Debitage: its Description and Distribution within the Stonehenge landscape. The Wiltshire Archaeological and Natural History Magazine 109, 1-14.

JONES, A. 2007: Memory and Material Culture (Cambridge).

JONES, I. 1725 edn.: The Most Notable Antiquity of Great Britain, Vulgarly Called Stonehenge, on Salisbury Plain Restored (London).

JUDD, J.W. 1902: Note on the nature and origin of the rock-fragments found in the excavations made at Stonehenge by Mr Gowland in 1901. Archaeologia 58(1), 106118.

LAMBARDE, W. 1730 edn.: Dictionarium Topographicum et Historicum (London).

LONG, C.E. (ed.) 1859: Diary of the marches kept by the Royal Army during the great civil war; kept by R. Symonds (London).

McOMISH, D., FIELD, D. and BROWN, G. 2002: The Field Archaeology of the Salisbury Plain Training Area (Swindon).

PARKER PEARSON, M. 2012: Stonehenge: exploring the greatest Stone Age mystery (London).

PARKER PEARSON, M. 2016: The sarsen stones of Stonehenge. Proceedings of the Geologists' Association 127, 363-9.

PARKER PEARSON, M., BEVINS, R., IXER, R., POLLARD, J., RICHARDS, C., WELHAM, K., CHAN, B., EDINBOROUGH, K., HAMILTON, D., MACPHAIL, R., SCHLEE, D., SCHWENNINSISGER, J-L., SIMMONS, E., SMITH, M. 2015: Craig 
Rhos-y-felin: a Welsh bluestone megalith quarry for Stonehenge. Antiquity 89(348), 1331-52.

PARKER PEARSON, M., POLLARD, J., RICHARDS, C., SCHLEE, D., WELHAM, K. 2016: In search of the Stonehenge Quarries. British Archaeology 146, 16-23.

PASSMORE, A.D. 1922: Notes on fieldwork in N. Wilts 1921-22 Wiltshire Archaeology Magazine 42 (137), 49-51.

PETRIE, W.M.F. 1880, 1989 edn.: Stonehenge: plans, description and theories (London).

PIGGOTT, S. 1962: The West Kennet Long Barrow Excavations 1955-56. Ministry of Works Archaeological Reports 4 (London).

PITTS, M. 2000: Hengeworld (London).

POLLARD, J. 2013: Renfrew's Monuments and Mobilisation 40 Years On. Neolithic Studies Group meeting. The Last Great Monuments: ceremonial complexes of the $3^{\text {rd }}$ millennium BC, 4 November 2013.

POLLARD, J. and GILLINGS, M. 1998: Romancing the stones: towards a virtual and elemental Avebury. Archaeological Dialogues 5(2), 140-64.

POLLARD, J. and GILLINGS, M. 2009: The World of the Grey Wethers. In O'CONNOR, B., COONEY, G. and CHAPMAN, J. (eds.), Materialitas. Working stone, carving identity (Oxford, Prehistoric Society Research Paper 3), 29-41.

RENFREW, C. 1973: Monuments, mobilization and social organisation in Neolithic Wessex. In RENFREW, C. (ed.), The Explanation of Culture Change: Models in Prehistory (London, Proceedings of a meeting of the Research Seminar in Archaeology and Related Subjects held at the University of Sheffield), 539-58. 
RICHARDS, C. 2004 Labouring with monuments: constructing the dolmen at Carreg Samson, south-west Wales. In CUMMINGS, V. and FOWLER, C. (eds.), The Neolithic of the Irish Sea (Oxford), 72-80.

RICHARDS, C. 2013: Interpreting Stone Circles. In RICHARDS, C. (ed.), Building the Great Stone Circles of the North (Oxford), 2-30.

SCOURSE, J.D. 1997: Transport of the Stonehenge Bluestones: testing the Glacial Hypothesis. In CUNLIFFE, B. and RENFREW, C. (eds.), Science and Stonehenge (Oxford, Proceedings of the British Academy 92), 271-314.

STONE, E.H. 1924, 2009 reprint: The Stones of Stonehenge (London).

STUKELEY, W. 1740, 1743: Stonehenge: A Temple Restor'd to the British Druids and Abury, A Temple of the British Druids (London).

TATTON-BROWN, T. 2001: The Quarrying and Distribution of Reigate Stone in the Middle Ages. Medieval Archaeology 45(1), 189-201.

THORPE, R.S., WILLIAMS-THORPE, O., GRAHAM JENKINS, D., WATSON, J.S. 1991: The Geological Sources and Transport of the Bluestones of Stonehenge, Wiltshire, UK. Proceedings of the Prehistoric Society 57(2), 103-157.

TILLEY, C., RICHARDS, C., BENNETT, W., FIELD, D. 2007: Stonehenge - its landscape and its architecture: a reanalysis. In LARSON, M. and PARKER PEARSON, M. (eds.), From Stonehenge to the Baltic (Oxford, BAR International Series 1692), 183-204.

THOMAS, H.H. 1923: The source of the stones of Stonehenge. The Antiquaries Journal 3, 239-60.

ULLYOTT, J.S. and NASH, D.J. 2016: Distinguishing pedogenic and non-pedogenic silcretes in the landscape and geological record. Proceedings of the Geologists' Association 127, 311-19. 
ULLYOT, J.S., NASH, D.J., WHITEMAN, C.A. and MORTIMORE, R.N. 2004:

Distribution, petrology and mode of development of silcretes (sarsens and puddingstones) on the eastern South Downs, UK. Earth Surface Processes and Landforms 29, 1509-39. 


\section{TABLES}

Table 1

Stonehenge stone identification numbers (following Petrie 1880) for extant sarsens and bluestones, using Cleal et al. (1995). Other tallies are reached depending on how fallen and broken stones are counted, and the definition of 'stump'.

\begin{tabular}{|c|c|c|c|c|c|}
\hline & \multicolumn{2}{|c|}{ SARSEN } & \multicolumn{3}{|c|}{ BLUESTONE } \\
\hline & $\begin{array}{l}\text { Upright/in } \\
\text { place }\end{array}$ & Fallen & Upright & Fallen & Stump \\
\hline $\begin{array}{l}\text { Stone } \\
\text { number }\end{array}$ & $\begin{array}{l}1,2,3,4,5,6, \\
7,10,11,16, \\
21,22,23,27, \\
28,29,30,51, \\
52,53,54,56, \\
57,58,60,91, \\
93,96,100, \\
102,105,107, \\
122,130,152, \\
154,158\end{array}$ & $\begin{array}{l}8,9,12,14, \\
15,19,25,26, \\
55,59,95, \\
120,127,156, \\
160\end{array}$ & $\begin{array}{l}31,33,34,37 \\
46,47,49,61 \\
62,64,65,68 \\
69,70\end{array}$ & $\begin{array}{l}32,35 \mathrm{~b}, 36, \\
38,39,40,41, \\
42,43,45,48, \\
67,71,72, \\
150\end{array}$ & $\begin{array}{l}32 \mathrm{c}, 32 \mathrm{~d}, 32 \mathrm{e}, \\
33 \mathrm{e}, 35 \mathrm{a}, 40 \mathrm{c}, \\
40 \mathrm{~g}, 41 \mathrm{~d}, 42 \mathrm{c}, \\
66\end{array}$ \\
\hline
\end{tabular}

Table 2

Packing stones in Stonehenge stoneholes 29, 30, 1, and 8 (Hawley 1922, 39, 40, 42, 44; Hawley 1926, 6).

\begin{tabular}{|c|c|c|c|}
\hline Sarsen & $\mathrm{N}$ identified packing stones & Stone type & $\mathrm{N}$ of stone type \\
\hline \multirow{4}{*}{29} & \multirow{4}{*}{47} & Flint & 2 \\
\hline & & Sarsen & 19 \\
\hline & & Chilmark and Hurdcott & 26 \\
\hline & & Chalk & rubble throughout \\
\hline \multirow{3}{*}{30} & \multirow{3}{*}{58} & Sarsen & "a few only" \\
\hline & & Glauconite and Chilmark & "chiefly" \\
\hline & & Chalk & rubble throughout \\
\hline \multirow{2}{*}{1} & \multirow{2}{*}{48} & Sarsen & "mostly" \\
\hline & & Glauconite and Chilmark & "about one-third" \\
\hline \multirow{3}{*}{8} & \multirow{3}{*}{43} & Oolite & "one or two" \\
\hline & & Sarsen & "mostly" \\
\hline & & Chalk & rubble to one side \\
\hline
\end{tabular}




\section{CAPTIONS OF ILLUSTRATIONS}

Figure 1

Stonehenge viewed from the north-east, including the causeway through the earthwork henge enclosure. The familiar sight of Stonehenge's immense sarsen stones has dominated debate about prehistoric social structures since William Stukeley proposed that the monument had been erected under the direction of druids (Katy Whitaker).

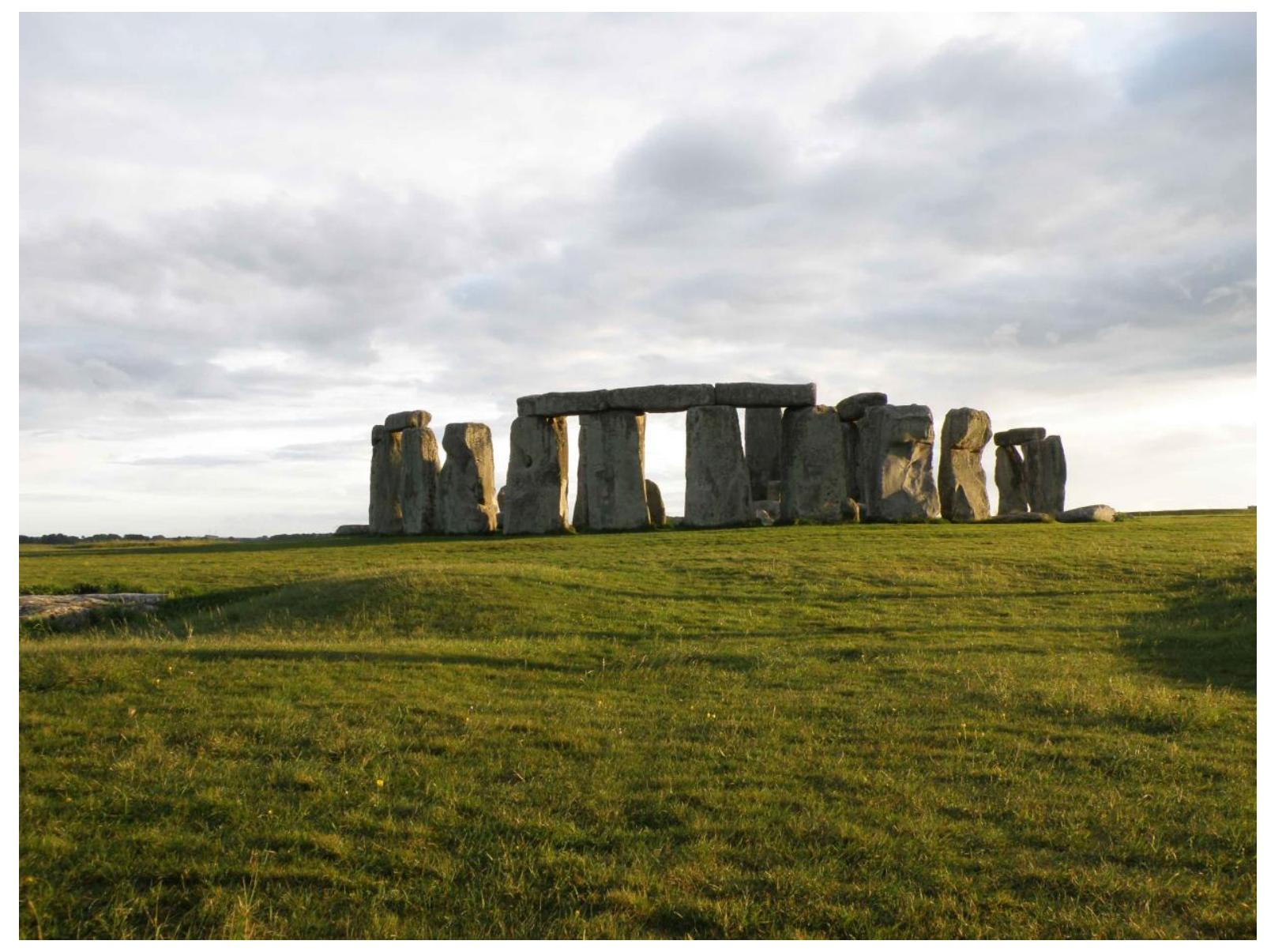


Figure 2

Chalk, depicted by green shades, dominates the bedrock geology of southern and central Wiltshire. The Vale of Pewsey (an anticline) and the Vale of Wardour (the valley of the River Nadder) cut through the chalk uplands. The valleys and the northwest facing scarp provide access to a variety of rock types.

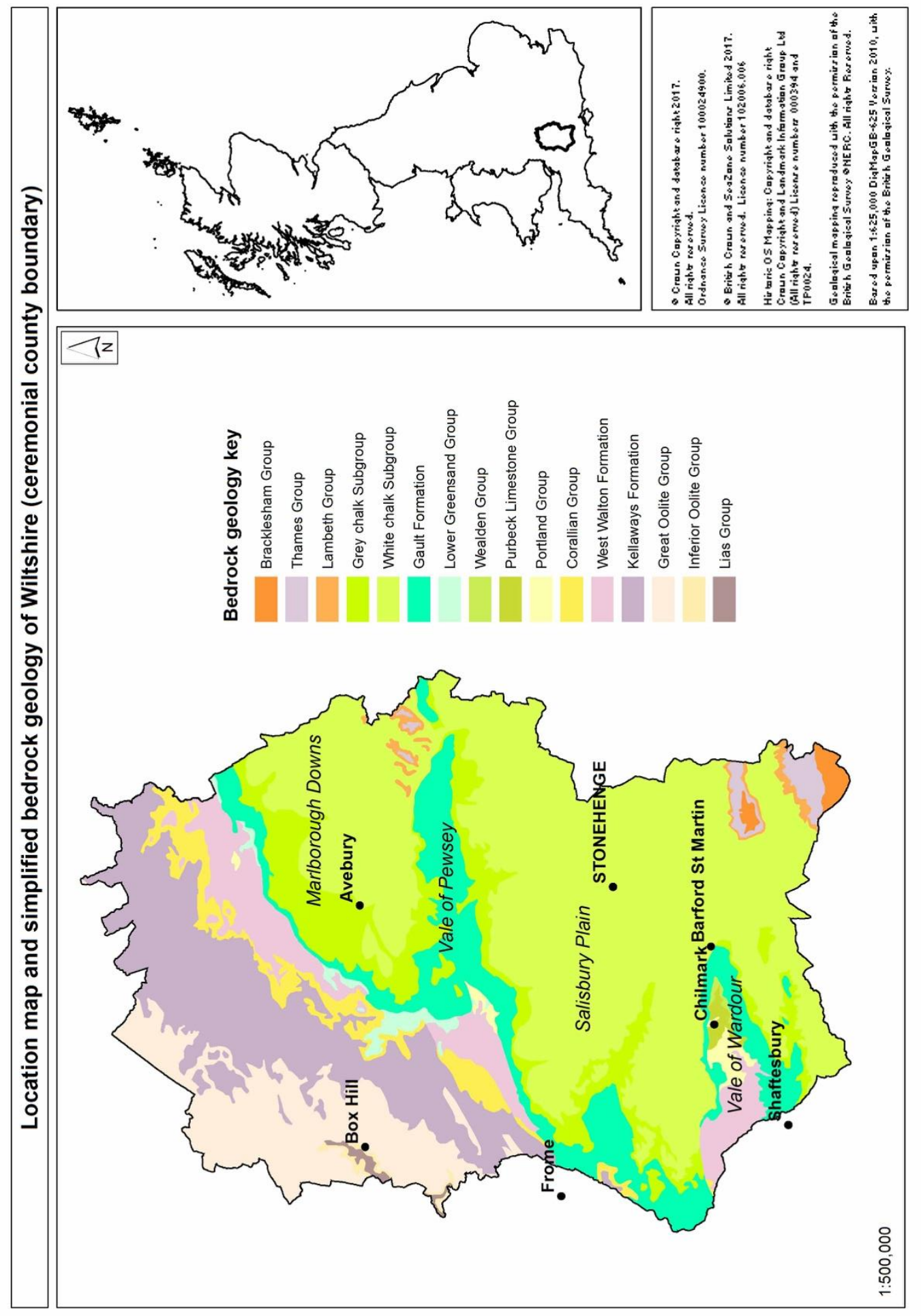




\section{Figure 3}

"a place so full of grey pibble stone of great bignes as is not usually seen...and in this parish, a myle and a half in length, they lye so thick as you may goe upon them all the way." (Richards Symonds, 1644). Sarsens in the Valley of Stones, Marlborough Downs (Wiltshire), hint at the visual effect that so struck Symonds (Katy Whitaker).

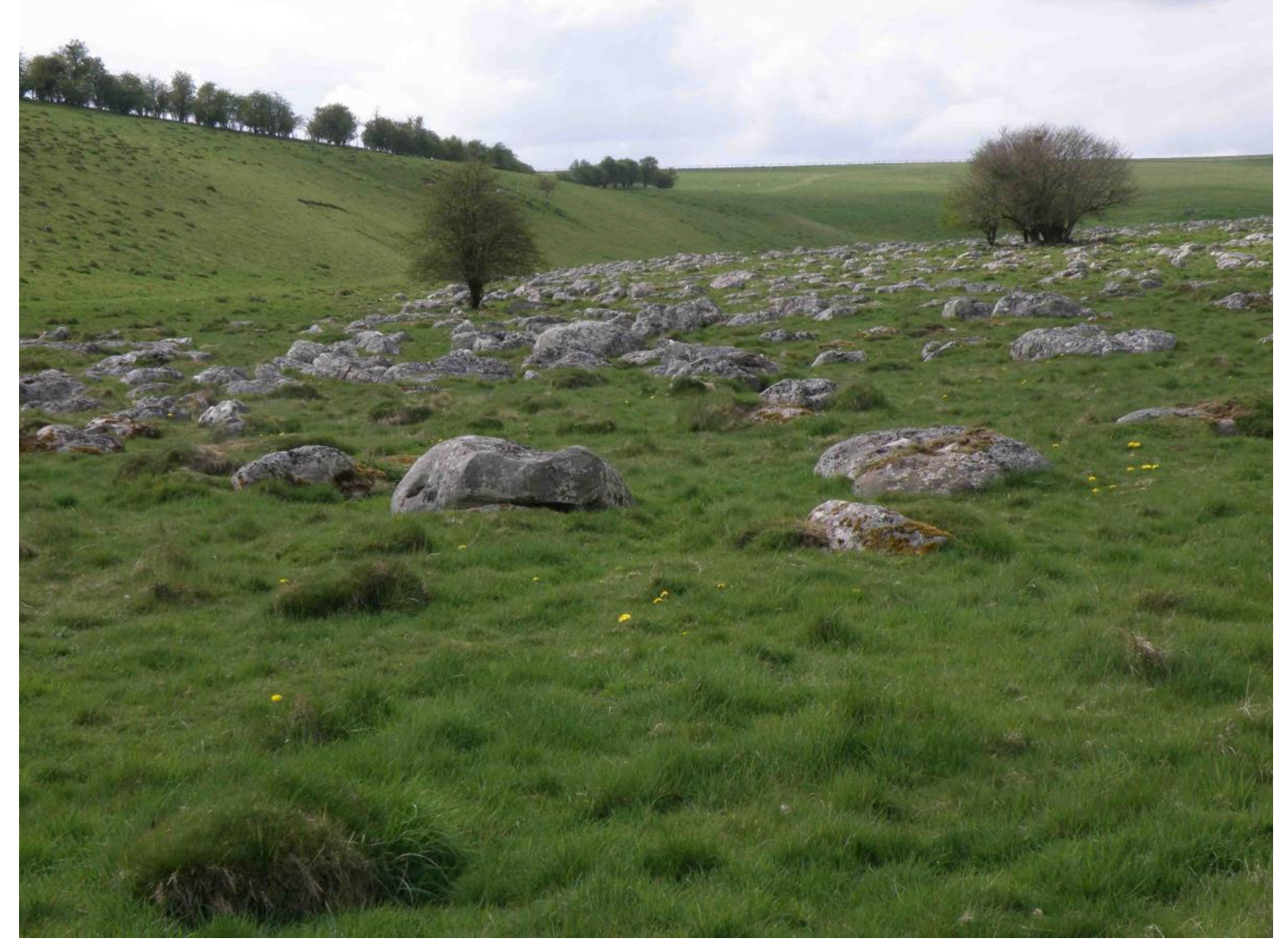


Figure 4

Houses in East Kennet, one of the 'sarsen villages' near Avebury (Wiltshire), are built in a variety of local materials. Sarsen stone, in the form of both rubble walling and cut blocks, is nevertheless a characteristic feature that contributes to the sense of place and has drawn the attention of commentators, over and above other media such as brick and cob walling (Katy Whitaker).

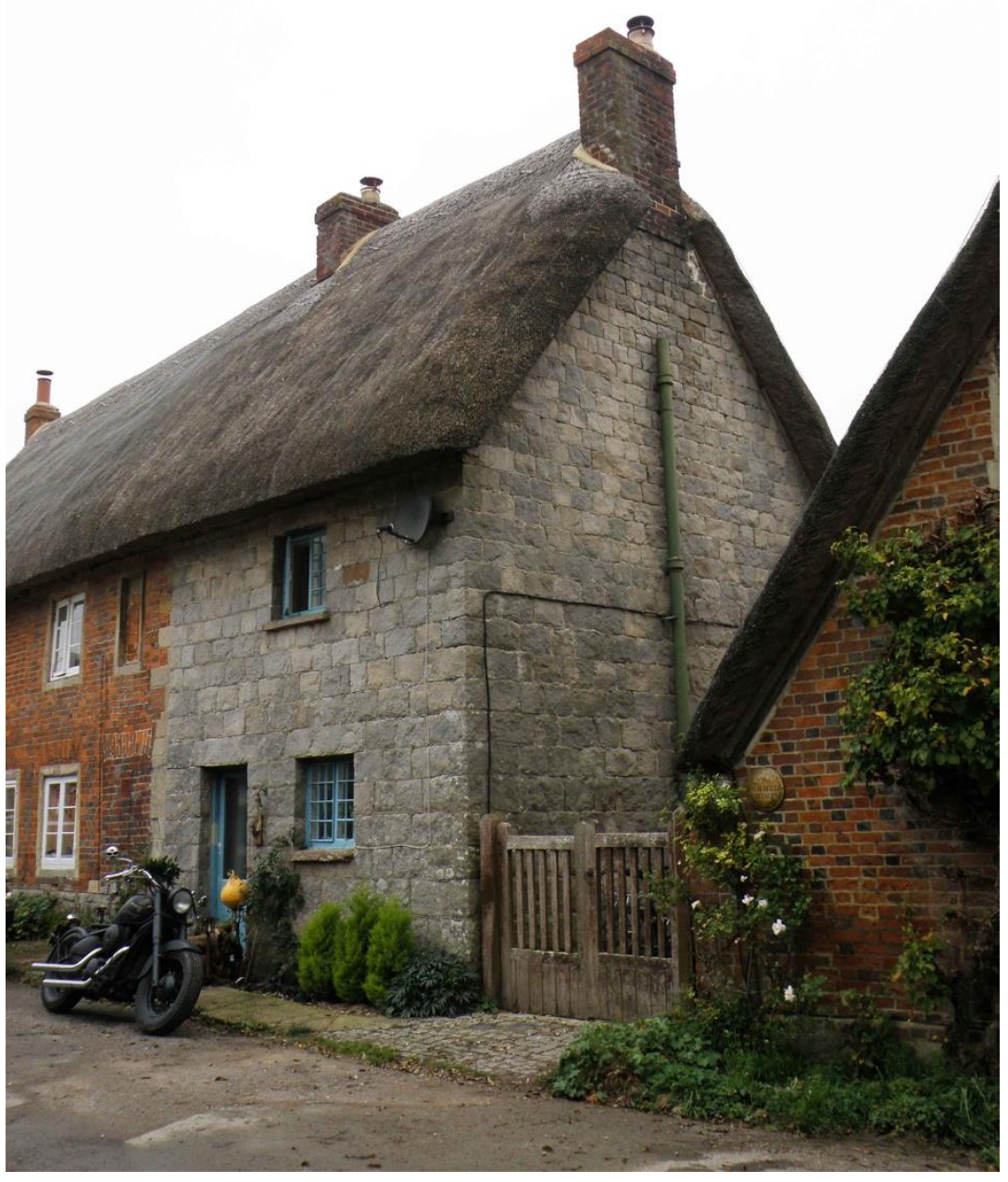




\section{Figure 5}

The Toad Stone in the Valley of Stones on the Marlborough Downs (Wiltshire), is one of the few remaining very large sarsens in this area. It stands well over $2 \mathrm{~m}$ tall. Slightly to one side of the adjacent natural sarsen spread, AD Passmore (1922) suggested that this boulder is out of place: he proposed it had been intended for the stone circles at Avebury a short distance to the west, was moved, and then abandoned by the builders (Katy Whitaker). 


\section{Figure 6}

An orange-brown sarsen set into the roadside outside The Anchor, Faversham, (Kent). This is one of a number of sarsens dotted around the wharves beside the River Stour in this part of the town. Although small sarsens are occasionally found buried in Tertiary and later deposits in this area (Holmes 1981), it is possible that these sarsens arrived as ballast in Thames wherries and were used, as this one, to keep road vehicles from hitting the closely-spaced buildings (Katy Whitaker).

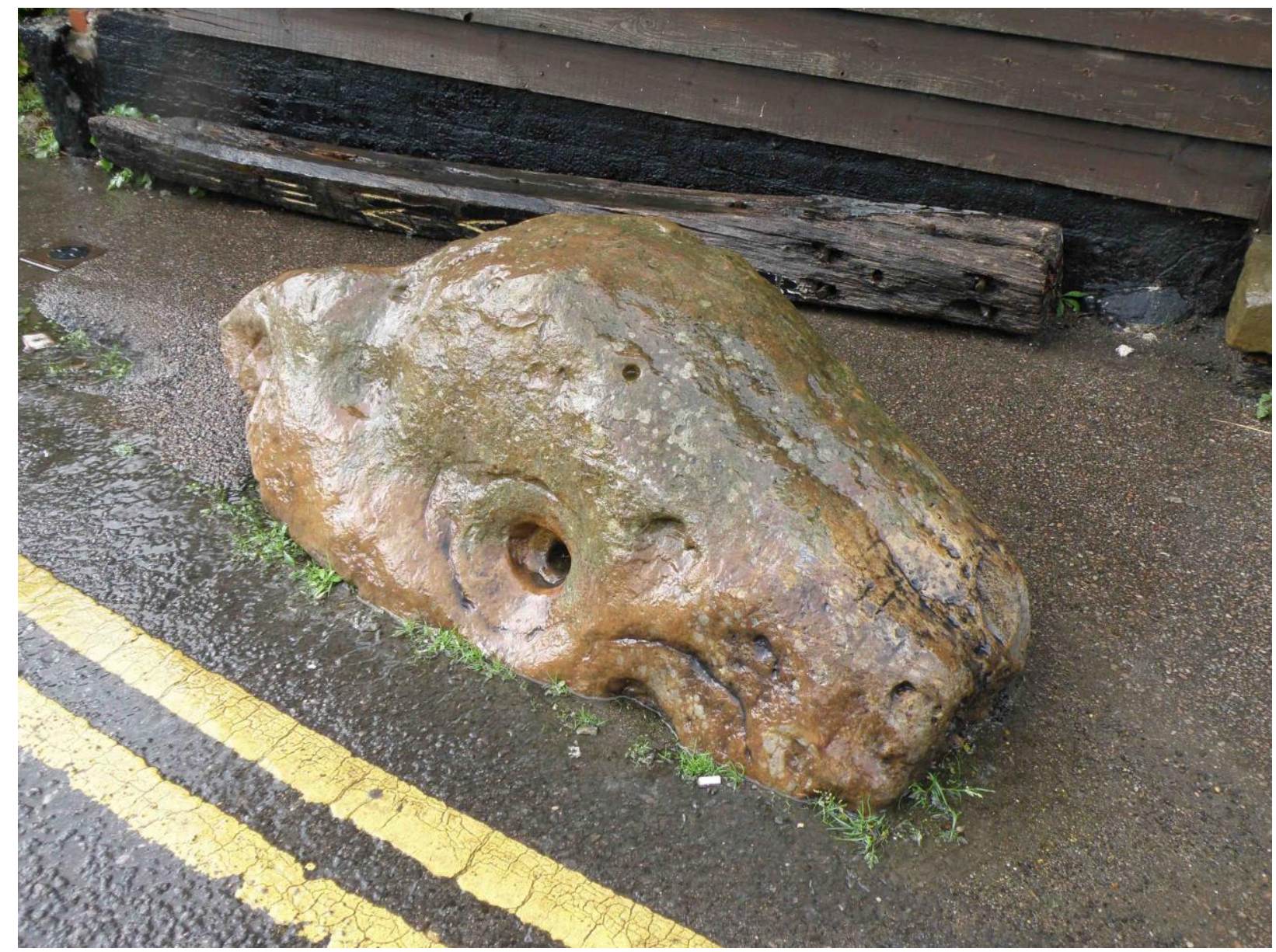

